\title{
FACTORS INFLUENCING THE DIURETIC RESPONSE OF SEATED SUBJECTS TO THE INGESTION OF ISOTONIC SALINE SOLUTION
}

\author{
BY WILLIAM H. BIRCHARD AND MAURICE B. STRAUSS \\ (From the Medical Service and Research Laboratory, Boston Veterans Administration Hospital, \\ and the Department of Medicine, Boston University School of Medicine, \\ Boston, Massachusetts)
}

(Submitted for publication April 7, 1952; accepted May 15, 1953)

The ingestion of isotonic saline solution, long considered to have little or no immediate effect on urine flow (1), has recently been shown by Blomhert (2) to be followed by brisk water diuresis. Further, several investigators have demonstrated that similar diuresis may result from intravenous infusion of isotonic saline solution $(2,3,4)$. Examination of the latter experiments reveals at least three factors which appear to be of importance in determining whether water diuresis ensues: hydration, posture and time of day. Thus Ladd (3) found that diuresis following saline infusion occurred only if the subjects had been prehydrated eight to thirteen hours before the infusion was given. A previous study from this laboratory (4) showed that diuresis occurred in recumbent subjects but not in those quietly seated in a chair. Blomhert (2) did not observe diuresis when infusion was accomplished at night, although it occurred regularly under the same conditions during the day.

Since Blomhert's studies were made only on recumbent subjects and no mention of posture is to be found in other reports concerning the response to ingested saline, it was deemed worthwhile to ascertain whether diuresis might be induced, and if so, under what circumstances, following saline ingestion by seated subjects.

\section{METHODS}

The subjects were essentially healthy male adults free of cardiovascular, renal and endocrine disease. Except for standing to void at appropriate intervals, they remained quietly seated in a straight backed chair during the study. Methods of analysis have been described in recent publications from this laboratory $(4,5)$.

\section{RESULTS}

A. Observations on the response to saline ingestion in trained subjects with and without prior hydration

The subjects were three physicians accustomed to the procedures involved and capable of voluntarily emptying their bladders at short intervals. In the first study the subjects drank approximately one liter of fluid with breakfast and collected urine at intervals until the flow had declined from its peak rate to less than $2 \mathrm{ml}$. per min. At this time one liter of 0.9 per cent saline was ingested within 10 minutes. In each instance the rate of urine flow increased briefly, reaching peak flows of $3.3,4.7$ and $5.9 \mathrm{ml}$. per min. in the third quarter hour and returning to the initial rate at the end of an hour. Data for one subject are shown in Figure 1. The other two subjects showed similar changes. Urinary electrolyte and creatinine concentrations as well as specific gravity fell. Urea and ammonia excretion were measured in one subject. The total solute concentration, estimated as the sum of urea plus twice the sodium, potassium, and ammonia (in order to include their accompanying anions), at the time of maximum flow was $185 \mathrm{mM}$ per L., definitely hypotonic to extracellular fluid. Creatinine excretion remained relatively constant ${ }^{1}$ suggesting that the diuresis resulted from diminished tubular reabsorption of water rather than increased filtration.

1 Since venipuncture, no matter how skillfully performed, might constitute an antidiuretic stimulus, no blood was obtained for analysis. However it is improbable that significant variation in serum creatinine occurred during the short time intervals involved. The validity of creatinine clearance as an index of glomerular filtration rate in normal man has been confirmed (6). 


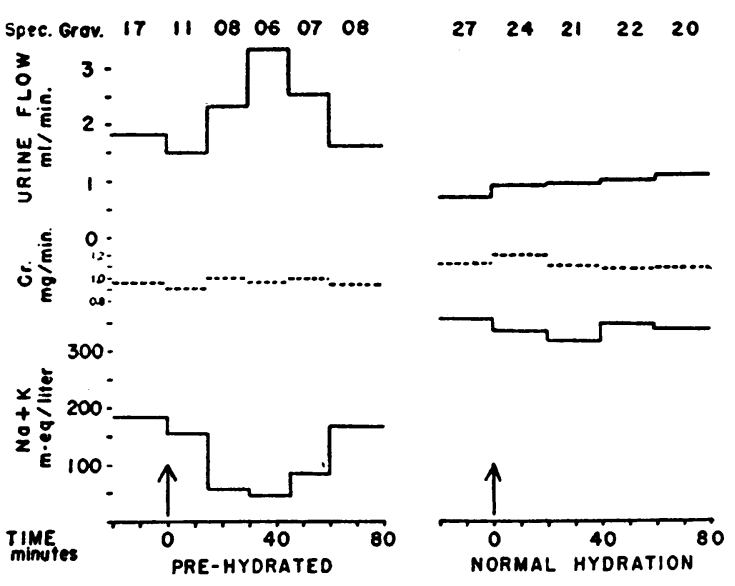

Fig. 1. The EFfect of the Ingestion of ONe Liter of 0.9 Per Cent Sodium Chloride Solution on Urinary Flow, Creatinine Excretion, Specific Gravity and Electrolyte Concentration With and Without PreHYDRATION

Saline was ingested in each case at the time indicated by the arrow. Only the last two digits of the specific gravity are shown.

When the saline was ingested under identical conditions save that fluids at breakfast were restricted to $250 \mathrm{ml}$. there occurred only a slight augmentation in urine flow (Figure 1). The other subjects reacted similarly.

At the end of one hour, when it was apparent that a diuretic response was not forthcoming, a second liter of saline was ingested during a period of ten minutes. Urine collections were continued for two hours. Diuresis did not occur. Endeavors to administer larger volumes of saline were frustrated by the appearance of mild cramps and frank diarrhea.

These observations indicate that in seated subjects who are on the descending limb of a previous water diuresis, transient but definite water diuresis may follow the ingestion of one liter of isotonic saline solution, but that in normally hydrated, seated subjects neither one nor two liters of ingested saline leads to such a response.

\section{B. Observations on normally hydrated subjects with and without prior salt loading}

Without previous preparation each of four subjects came to the laboratory one to two hours after a breakfast in which fluids were restricted to 250 ml. Following the collection of timed control urine specimens, blood was obtained for analysis and the subject drank one liter of 0.9 per cent saline solution within 10 to 20 minutes. Urine was obtained at approximately hourly intervals thereafter for the next three hours. During the remainder of the afternoon, but before 6 P.M., the subject drank sufficient 0.9 per cent saline solution, to constitute together with the initial liter, a load of $6.2 \mathrm{mEq}$. per $\mathrm{Kg}^{2}{ }^{2}$ The subjects ate their usual meals (with salt as desired) and took whatever additional liquids they wished. The following morning the procedure of the preceding day insofar as venipuncture, urine collections and saline ingestion were concerned was repeated.

In each instance when saline was ingested without antecedent administration of extra salt there was a minor increase in urine flow associated with an increased concentration of salt therein (Table I).

Following the salt loading there was in each instance a gain of weight (average $0.9 \mathrm{Kg}$.) ascribable to an increase in the volume of extracellular fluid (Table II). Although the initial urine flow was distinctly greater than on the preceding day, so was the rate of sodium chloride excretion, as a result of which the urinary electrolyte concentration differed little from that which obtained 24 hours earlier.

Following the ingestion of saline, diuresis commenced promptly, reaching peak flows of 5.0 to $8.9 \mathrm{ml}$. per min. within an hour and accompanied by a sharp fall in the concentration of electrolytes, in creatinine $U / P$ ratio and in urinary specific gravity. Creatinine clearances exhibited no consistent changes. In one subject in whom urea concentration was determined, the sum of the concentration of urea plus $2(\mathrm{Na}+\mathrm{K})$, an estimate of the total urinary solutes, had declined to $152 \mathrm{mM}$ per L., at the time of maximum diuresis, or approximately one-half the osmolarity of extracellular fluid.

In the other three experiments hypotonicity of the urine to the plasma at the time of maximum diuresis may be inferred in view of the fact that the concentration of the major urinary electrolytes $(2 \mathrm{Na}+\mathrm{K})$ was between 102 and $175 \mathrm{mM}$ per $\mathrm{L}$.

2 In the case of subject WHB the salt loading was accomplished three days later rather than on the same day. 
TABLE I

The effect of the ingestion of isotonic saline solution on urine flow and specific gravity, concentration of electrolytes, creatinine $U / P$ ratio and clearance, and sodium excretion, before and after pre-loading with saline

\begin{tabular}{|c|c|c|c|c|c|c|c|c|c|}
\hline \multirow[b]{2}{*}{$\begin{array}{l}\text { Subject } \\
\text { Period }\end{array}$} & \multirow[b]{2}{*}{ Time } & \multicolumn{8}{|c|}{ Urine } \\
\hline & & Flow & $\begin{array}{l}\text { Spec. } \\
\text { Grav.* }\end{array}$ & $\mathbf{N a}$ & $\mathbf{K}$ & $\mathrm{Cl}$ & $\mathrm{Cr}_{\mathrm{r}}$ & $C_{o r}$ & $\mathbf{N a}$ \\
\hline & Minutes & $\operatorname{ml.} / \min$. & & $m E q . / L$ & $m E q . / L$ & $m E q . / L$. & $\underset{\text { ratio }}{U / P}$ & $m l . / m i n$ & $\underset{\text { micro. }}{\min }$ \\
\hline $\begin{array}{l}\text { WHB } \\
\text { Control }\end{array}$ & $\begin{array}{r}\text { Pre† } \\
+\quad 60 \\
+123 \\
+189\end{array}$ & $\begin{array}{l}0.5 \\
0.7 \\
0.7 \\
1.0\end{array}$ & $\begin{array}{l}26 \\
24 \\
24 \\
22\end{array}$ & $\begin{array}{l}150 \\
180 \\
143 \\
160\end{array}$ & $\begin{array}{r}94 \\
107 \\
166 \\
178\end{array}$ & $\begin{array}{l}220 \\
264 \\
304 \\
312\end{array}$ & $\begin{array}{l}276 \\
267 \\
249 \\
129\end{array}$ & $\begin{array}{l}138 \\
187 \\
174 \\
129\end{array}$ & $\begin{array}{r}75 \\
120 \\
97 \\
155\end{array}$ \\
\hline $\begin{array}{l}\text { After } \\
\text { pre-- } \\
\text { loading }\end{array}$ & $\begin{array}{r}\text { Pre } \\
+33 \\
+\quad 68 \\
+100 \\
+138\end{array}$ & $\begin{array}{l}2.4 \\
8.9 \\
7.0 \\
2.7 \\
2.2\end{array}$ & $\begin{array}{l}15 \\
04 \\
06 \\
14 \\
14\end{array}$ & $\begin{array}{r}240 \\
77 \\
93 \\
214 \\
202\end{array}$ & $\begin{array}{l}38 \\
11 \\
15 \\
49 \\
61\end{array}$ & $\begin{array}{r}265 \\
80 \\
101 \\
222 \\
237\end{array}$ & $\begin{array}{l}75 \\
19 \\
22 \\
57 \\
68\end{array}$ & $\begin{array}{l}180 \\
166 \\
154 \\
153 \\
150\end{array}$ & $\begin{array}{l}584 \\
680 \\
655 \\
588 \\
440\end{array}$ \\
\hline $\begin{array}{l}\text { CT } \\
\text { Control }\end{array}$ & $\begin{array}{r}\text { Pre } \\
+60 \\
+120 \\
+180\end{array}$ & $\begin{array}{l}0.3 \\
0.7 \\
0.6 \\
0.7\end{array}$ & $\begin{array}{l}30 \\
21 \\
24 \\
24\end{array}$ & $\begin{array}{l}169 \\
202 \\
266 \\
256\end{array}$ & $\begin{array}{r}110 \\
50 \\
82 \\
83\end{array}$ & $\begin{array}{l}232 \\
216 \\
293 \\
326\end{array}$ & $\begin{array}{l}347 \\
174 \\
190 \\
180\end{array}$ & $\begin{array}{l}104 \\
122 \\
114 \\
126\end{array}$ & $\begin{array}{r}49 \\
145 \\
155 \\
184\end{array}$ \\
\hline $\begin{array}{l}\text { After } \\
\text { pre- } \\
\text { loading }\end{array}$ & $\begin{array}{r}\text { Pre } \\
+31 \\
+\quad 67 \\
+102 \\
+135\end{array}$ & $\begin{array}{l}2.1 \ddagger \\
7.7 \ddagger \\
8.7 \\
2.9 \\
3.0\end{array}$ & $\begin{array}{l}13 \\
06 \\
04 \\
13 \\
13\end{array}$ & $\begin{array}{c}186 \\
69 \ddagger \\
50 \\
187 \\
200\end{array}$ & $\begin{array}{c}24 \\
6 \ddagger \\
5 \\
21 \\
25\end{array}$ & $\begin{array}{c}216 \\
66 \ddagger \\
51 \\
192 \\
223\end{array}$ & $\begin{array}{l}70 \ddagger \\
19 \ddagger \\
16 \\
51 \\
51\end{array}$ & $\begin{array}{l}147 \ddagger \\
147 \ddagger \\
137 \\
148 \\
153\end{array}$ & $\begin{array}{l}398 \ddagger \\
532 \ddagger \\
438 \\
545 \\
600\end{array}$ \\
\hline $\begin{array}{l}\mathrm{AC} \\
\text { Control }\end{array}$ & $\begin{array}{r}\text { Pre } \\
+60 \\
+120\end{array}$ & $\begin{array}{l}0.7 \\
1.0 \\
1.0\end{array}$ & $\begin{array}{l}22 \\
18 \\
19\end{array}$ & $\begin{array}{r}90 \\
93 \\
114\end{array}$ & $\begin{array}{r}96 \\
92 \\
105\end{array}$ & $\begin{array}{l}141 \\
152 \\
190\end{array}$ & $\begin{array}{l}180 \\
122 \\
115\end{array}$ & $\begin{array}{l}126 \\
122 \\
115\end{array}$ & $\begin{array}{r}60 \\
95 \\
118\end{array}$ \\
\hline $\begin{array}{l}\text { After } \\
\text { pre- } \\
\text { loading }\end{array}$ & $\begin{array}{r}\text { Pre } \\
+\quad 30 \\
+60 \\
+\quad 90 \\
+120\end{array}$ & $\begin{array}{l}1.7 \\
3.5 \\
5.0 \\
1.6 \\
2.1\end{array}$ & $\begin{array}{l}15 \\
08 \\
06 \\
15 \\
14\end{array}$ & $\begin{array}{r}137 \\
67 \\
47 \\
201 \\
182\end{array}$ & $\begin{array}{l}33 \\
22 \\
16 \\
44 \\
48\end{array}$ & $\begin{array}{r}156 \\
72 \\
47 \\
215 \\
210\end{array}$ & $\begin{array}{l}79 \\
39 \\
24 \\
78 \\
60\end{array}$ & $\begin{array}{l}134 \\
136 \\
119 \\
125 \\
126\end{array}$ & $\begin{array}{l}228 \\
233 \\
233 \\
329 \\
383\end{array}$ \\
\hline $\begin{array}{l}\text { RD\& } \\
\text { Control }\end{array}$ & $\begin{array}{r}\text { Pre } \\
+60 \\
+123 \\
+163\end{array}$ & $\begin{array}{l}0.4 \\
0.6 \\
0.9 \\
1.0\end{array}$ & $\begin{array}{l}17 \\
22 \\
22 \\
22\end{array}$ & $\begin{array}{r}79 \\
53 \\
100 \\
128\end{array}$ & $\begin{array}{r}107 \\
138 \\
89 \\
105\end{array}$ & $\begin{array}{l}114 \\
122 \\
172 \\
205\end{array}$ & $\begin{array}{l}270 \\
197 \\
143 \\
125\end{array}$ & $\begin{array}{l}108 \\
118 \\
129 \\
125\end{array}$ & $\begin{array}{r}31 \\
32 \\
92 \\
121\end{array}$ \\
\hline $\begin{array}{l}\text { After } \\
\text { pre-- } \\
\text { loading }\end{array}$ & $\begin{array}{r}\text { Pre } \\
+30 \\
+60 \\
+\quad 90 \\
+120\end{array}$ & $\begin{array}{l}2.4 \\
1.3 \\
6.6 \\
2.3 \\
3.5\end{array}$ & $\begin{array}{l}11 \\
20 \\
03 \\
14 \\
11\end{array}$ & $\begin{array}{r}143 \\
214 \\
51 \\
184 \\
131\end{array}$ & $\begin{array}{r}24 \\
34 \\
8 \\
32 \\
30\end{array}$ & $\begin{array}{r}147 \\
211 \\
50 \\
193 \\
146\end{array}$ & $\begin{array}{r}55 \\
100 \\
21 \\
60 \\
39\end{array}$ & $\begin{array}{l}132 \\
130 \\
138 \\
138 \\
137\end{array}$ & $\begin{array}{l}341 \\
286 \\
334 \\
428 \\
459\end{array}$ \\
\hline
\end{tabular}

* Only the last two digits are given.

$\dagger$ Pre = Control period before saline ingestion.

$\ddagger$ The actual values obtained for these two periods indicate incomplete bladder emptying at the end of the control period and have been corrected by creatinine excretion on the assumption that the actual creatinine clearance remained constant.

$\$$ Urinary urea + ammonia concentration in subject RD was $488,406,371$ and $351 \mathrm{mM} / \mathrm{L}$. in the control study and $88,131,34,88$ and $63 \mathrm{mM} / \mathrm{L}$. in the study after pre-loading with salt.

\section{Observations on hydropenic subjects with and without prior salt loading}

In order to determine the effect of prior salt loading under conditions of moderate hydropenia each of the five subjects was studied in the "basal" state, i.e., deprived of food and fluid overnight, prior to ingesting the test dose of saline. In none of these subjects did diuresis follow the ingestion of saline prior to pre-loading with salt solution. Following such pre-loading, however, two of the subjects responded to saline ingestion with diureses identical to those of non-hydropenic subjects, achieving peak flows of 6.5 and $8.0 \mathrm{ml}$. per min. with corresponding declines in specific grav- 
ity and electrolyte concentration. The remaining three subjects exhibited little or no change in urine flow after saline ingestion. Thus it would appear that in the presence of an osmotic stimulus to antidiuresis from dehydration, saline ingestion may or may not be followed by an increased flow of dilute urine even when the subject has been pre-loaded with salt.

\section{DISCUSSION}

Blomhert has clearly shown that water diuresis may follow the ingestion of isotonic saline solution by normally hydrated recumbent subjects (2). The observations reported here, all made on seated subjects, may be summarized in tabular fashion according to 1) the state of hydration, 2) the prior ingestion of a salt-load, and 3 ) the occurrence of diuretic response :

$\begin{array}{lll}\begin{array}{c}\text { State of } \\ \text { hydration }\end{array} & \begin{array}{c}\text { Previous } \\ \text { salt } \\ \text { loading }\end{array} & \begin{array}{c}\text { Diuretic } \\ \text { response }\end{array} \\ \begin{array}{l}\text { Slight hydropenia } \\ \text { Normal }\end{array} & \text { None } & 0 / 5 \\ \text { Slightly increased } & \text { None } & 0 / 7 \\ \text { Slight hydropenia } & \text { None } & 3 / 3 \text { transient, } \\ \text { Normal } & \text { Yes } & 2 / 5 \text { brisht } \\ \text { Norisk }\end{array}$

The absence of water diuresis following the ingestion of one to two liters of isotonic saline by hydrated seated subjects was not surprising in view of the fact that the intravenous infusion of three liters of isotonic saline is similarly ineffective in seated subjects (4).

The observation that when antidiuretic activity presumably was relatively low (as when trained subjects were on the descending limb of a previous water diuresis), definite if slight and transient water diuresis followed the ingestion of one liter of isotonic saline, although this did not occur when these subjects ingested saline under conditions of normal hydration, suggests an interplay of forces upon the mechanism or mechanisms involved : normal hydration and the sitting position constituting slight antidiuretic stimuli and saline ingestion a moderate diuretic stimulus. These subjects, by virtue of their familiarity with the procedures involved, may be considered to have been free of significant emotional antidiuretic stimuli.

Since there is no reason to believe that water is preferentially absorbed from the gastrointestinal tract when isotonic saline is ingested, it is unlikely that alterations in the effective osmotic pressure of the plasma and extracellular fluid explain the diuresis observed. The suggestion has been made on the basis of the studies cited above $(3,4)$ as well as others $(7,8)$ that critical changes in the volume or distribution of the extracellular fluid or alternatively in plasma volume or distribution, may mediate true water diuresis (9).

The inability of normal man rapidly to dispose of a large isotonic saline load affords a simple means of further examining this hypothesis through the administration of such a load on the day preceding the test dose of saline. Although such a load, with the excess of chloride, might conceivably elevate serum chloride levels, no changes of significance were noted (Table II). The decline in serum total proteins, hemoglobin and hematocrit all suggest an expansion of plasma volume. The average gain of $900 \mathrm{Gm}$. in weight above that of the preceding morning is readily ascribable to an expansion of extracellular fluid volume in both interstitial and plasma compartments. In contrast to sitting subjects receiving isotonic saline intravenously who frequently exhibit slight pitting edema of the legs, these subjects who received saline on the preceding day, awoke on the next morning with perceptible puffiness about the eyes and no edema of the legs. The impression is thus gained that the distribution of the presumed $900 \mathrm{ml}$. increase in extracellular volume was different from that obtaining when a similar or even larger expansion was accomplished in the sitting position without an intervening period of recumbency.

Whatever the difference may be, however, it is clear that the pre-loaded subjects, being seated in a chair and normally hydrated, developed a prompt water diuresis when they ingested a liter of saline on the following morning. This did not occur in any instance under comparable circumstances when the subjects were not pre-loaded with salt. The fact that three of the five subjects who were given saline under the same conditions save for the fact that they had had no fluids for 12 hours, failed to exhibit diuresis, suggests that the osmotic stimulus to antidiuresis thus present from hydropenia was sufficient to prevent the response. Such an interplay of factors has been 
TABLE II

The effect of pre-loading with saline on body weight and on the constituents of the blood and the volume of plasma

\begin{tabular}{|c|c|c|c|c|c|c|c|c|c|}
\hline \multirow[b]{3}{*}{$\begin{array}{l}\text { Subject } \\
\text { Period }\end{array}$} & \multirow[b]{3}{*}{$\begin{array}{c}\text { Weight } \\
K_{\boldsymbol{g}} .\end{array}$} & \multirow{2}{*}{\multicolumn{4}{|c|}{ Serum }} & \multirow{2}{*}{\multicolumn{2}{|c|}{ Blood }} & \multicolumn{2}{|c|}{$\mathrm{PV}_{2} / \mathrm{PV}_{1} \times 100^{*}$} \\
\hline & & & & & & & & \multirow{2}{*}{$\begin{array}{c}\text { From } \\
\text { Hct. and } \\
\text { Hgb. } \\
\text { per cent }\end{array}$} & \multirow{2}{*}{$\begin{array}{c}\text { From } \\
\text { TP } \\
\text { per cen }\end{array}$} \\
\hline & & $\underset{m E q . / L}{\mathrm{Na}}$ & $\underset{m E q . / L}{\mathrm{~K}}$ & $\underset{m E q . / L .}{\mathrm{Cl}}$ & $\underset{G m . \%}{\mathrm{TP}}$ & $\underset{\text { Gm. }}{\mathrm{Hgb} .}$ & $\underset{\text { Vol. } \%}{\text { Hct. }}$ & & \\
\hline $\begin{array}{l}\text { WHB } \\
\text { Control } \\
\text { Pre-loaded }\end{array}$ & $\begin{array}{l}63.87 \\
64.53\end{array}$ & $\begin{array}{l}142 \\
141\end{array}$ & $\begin{array}{l}4.5 \\
4.4\end{array}$ & $\begin{array}{l}108 \\
106\end{array}$ & $\begin{array}{l}6.8 \\
6.5\end{array}$ & $\begin{array}{l}14.6 \\
14.6\end{array}$ & $\begin{array}{l}48.0 \\
46.2\end{array}$ & $\begin{array}{l}100 \\
104\end{array}$ & $\begin{array}{l}100 \\
105\end{array}$ \\
\hline $\begin{array}{l}\text { CT } \\
\text { Control } \\
\text { Pre-loaded }\end{array}$ & $\begin{array}{l}72.60 \\
73.70\end{array}$ & $\begin{array}{l}142 \\
140\end{array}$ & $\begin{array}{l}4.4 \\
4.2\end{array}$ & $\begin{array}{l}105 \\
106\end{array}$ & $\begin{array}{l}7.2 \\
6.8\end{array}$ & $\begin{array}{l}15.4 \\
13.3\end{array}$ & $\begin{array}{l}49.0 \\
46.0\end{array}$ & $\begin{array}{l}100 \\
123\end{array}$ & $\begin{array}{l}100 \\
105\end{array}$ \\
\hline $\begin{array}{l}\text { AC } \\
\text { Control } \\
\text { Pre-loaded }\end{array}$ & $\begin{array}{l}69.11 \\
70.00\end{array}$ & $\begin{array}{l}144 \\
142\end{array}$ & $\begin{array}{l}4.6 \\
4.3\end{array}$ & $\begin{array}{l}103 \\
102\end{array}$ & $\begin{array}{l}7.5 \\
6.9\end{array}$ & $\begin{array}{l}15.8 \\
12.9\end{array}$ & $\begin{array}{l}47.2 \\
44.2\end{array}$ & $\begin{array}{l}100 \\
129\end{array}$ & $\begin{array}{l}100 \\
109\end{array}$ \\
\hline $\begin{array}{l}\text { RD } \\
\text { Control } \\
\text { Pre-loaded }\end{array}$ & $\begin{array}{l}63.90 \\
65.08\end{array}$ & $\begin{array}{l}141 \\
144\end{array}$ & $\begin{array}{l}4.4 \\
4.7\end{array}$ & $\begin{array}{l}103 \\
107\end{array}$ & $\begin{array}{l}7.0 \\
6.8\end{array}$ & $\begin{array}{l}15.2 \\
15.3\end{array}$ & $\begin{array}{l}46.0 \\
44.1\end{array}$ & $\begin{array}{l}100 \\
103\end{array}$ & $\begin{array}{l}100 \\
103\end{array}$ \\
\hline
\end{tabular}

* $\mathrm{PV}_{2} / \mathrm{PV}_{1} \times 100$ indicates the calculated ratio of the new to the original plasma volume expressed as per cent The formulae employed are:
1. $\frac{P V_{2}}{P_{1}}=\frac{\left(1-H c t_{2}\right)}{\left(1-H c t_{1}\right)} \times \frac{H_{g b_{1}}}{\mathrm{Hgb}_{2}}$
2. $\frac{\mathrm{PV}_{2}}{\mathrm{PV}_{1}}=\frac{\mathrm{TP}_{1}}{\mathrm{TP}_{2}}$

noted in connection with alcohol induced diuresis, which can be largely eliminated by giving dry salt with the alcohol and thus producing an osmotic antidiuretic stimulus (10).

In each instance when diuresis was observed in the above experiments it was associated with a decreased electrolyte concentration in the urine, a decreased creatinine $U / P$ ratio and an unchanged rate of creatinine excretion or clearance. Urinary specific gravity fell and the rate of electrolyte excretion showed little change or moderate increase. When this type of diuretic response follows the administration of water or hypotonic solutions it is presumed to be due to diminished antidiuretic hormone secretion. It may be noted parenthetically that although direct evidence is available indicating the responsiveness of the canine neurohypophysis (or some structure lying within the distribution of the internal carotid artery) to hypertonicity (11), the effect of hypotonicity is inferential. Since no other mechanism is known which leads to precisely this type of diuresis in man, the hypothesis that the water diuresis observed in the present experiments is mediated through the supra-opticohypophyseal system seems not unreasonable.

\section{CONCLUSIONS}

1. The ingestion of one or two liters of 0.9 per cent saline solution by normally hydrated sitting subjects is not followed by a water diuresis.

2. The ingestion of one liter of 0.9 per cent saline solution by seated subjects who are on the descending limb of a previously induced water diuresis may be followed by a slight and transient augmentation of urine flow.

3. The ingestion of one liter of 0.9 per cent saline solution by normally hydrated seated subjects who have ingested excess salt on the preceding day (and whose extracellular fluid volume has presumably been expanded thereby) is followed by a prompt water diuresis. This does not occur regularly if the subjects are moderately hydropenic.

4. Responsiveness of the supra-opticohypophyseal system to changes in the volume or distribution of extracellular fluid is inferred.

\section{ACKNOWLEDGMENT}

The technical assistance of Miss Elsie C. Rossmeisl, Miss Regina McLean, Miss Miriam Halpin, and Miss Ellen Vaznelis is gratefully acknowledged. 


\section{REFERENCES}

1. Smith, H. W., The Kidney. Structure and Function in Health and Disease. Oxford University Press, New York, 1951.

2. Blomhert, G., Over de Zogenaamde Waterdiurese. Thesis, University of Amsterdam, Scheltema \& Holkema, Amsterdam, 1951.

3. Ladd, M., Effect of prehydration on the response to saline infusion in man. J. Appl. Physiol., 1951, 3, 379.

4. Strauss, M. B., Davis, R. K., Rosenbaum, J. D., and Rossmeisl, E. C., "Water diuresis" produced during recumbency by the intravenous infusion of isotonic saline solution. J. Clin. Invest., 1951, 30, 862.

5. Rosenbaum, J. D., Ferguson, B. C., Davis, R. K., and Rossmeisl, E. C., The influence of cortisone upon the diurnal rhythm of renal excretory function. J. Clin. Invest., 1952, 31, 507.
6. Brod, J., and Sirota, J. H., The renal clearance of endogenous "creatinine" in man. J. Clin. Invest., 1948, 27, 645.

7. Leaf, A., and Mamby, A. R., An antidiuretic mechanism not regulated by extracellular fluid tonicity. J. Clin. Invest., 1952, 31, 60.

8. Welt, L. G., and Orloff, J., The effects of an increase in plasma volume on the metabolism and excretion of water and electrolytes by normal subjects. J. Clin. Invest., 1951, 30, 751.

9. Smith, H. W., The renal excretion of sodium and water. Federation Proc., 1952, 11, 701.

10. Strauss, M. B., Rosenbaum, J. D., and Nelson, W. P., III, The effect of alcohol on the renal excretion of water and electrolyte. J. Clin. Invest., 1950, 29, 1053.

11. Verney, E. B., Absorption and excretion of water. The antidiuretic hormone. Lancet, 1946, 2, 739, 781. 